\title{
国望。舅勘）治具・クランプ技術の動向と展望 ーフレキシブルフィクスチャリングー
}

Future and Trend of Jig and Clamp Technology

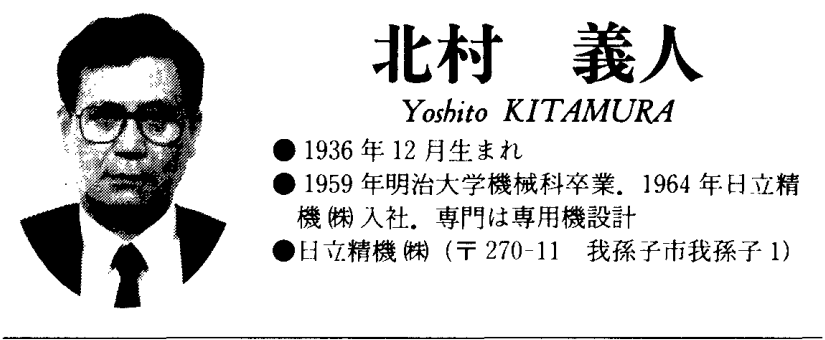

\section{1. まえがき}

工作機械は, 1950 年代に NC 工作機械が世の 中に出てから今日までの 40 年間に，めざましい 発展を遂げたが，工作機械と表裏一体である取付 具は, 40 年前とほとんど変わっていないように 見える. しかし, 一つには, 製品の高性能化, 高 信頼化への対応で, 対象加工物の高精度化, 形状 の複雑化に応じた変化が見られる。

例えば，ビデオ，レーザ，コンパクトディス ク, コンピュータ部品, 科学計測器等, 新しく出 てきた高精度部品は, 高精度の上, 軽くて薄いも のが多いため, 加工精度にクランプひずみの影響 を受けない,また，ビリを発生させないような取 付具の研究改善が行われている(1) (3). これらの 保持例として, 機械的 3 点固定法, 真空チャック 法, 軟接着法等に加えて, 近年, 冷凍チャック法 が開発され，実用化されている。この方法は，加 工物形状に融通性があり，クランプひずみも受け ずに，自然の状態で固定できる利点がある，また 最大の欠点であった脱着時間も改善され, 量産用 取付具としても最近注目されている。

一方, 自動車部品に代表される量産部品に対し ては，近年ますます消費者の嗜好が差別化，高級 化に進み，製品を供給する側も，消費者ニーズの 多様化に対応するため, 画一的な量産体制から多 品種少量生産体制に移行してきている。

多品種少量生産といっても, トータル生産量は あまり変化がないため, 品種の増えた分, 専用ラ インで平衡生産するか, または, フレキシブル生

Jour. JSME

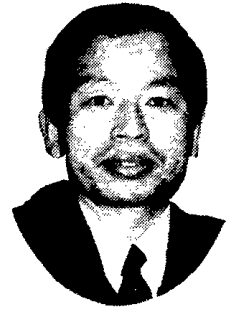

桜井征支朗

Seishiro SAKURAI

1938 年 5 月生まれ

1961 年富山大学機械科卒業. 同年日立精機 入社, 専門は専用機, 治具設計

日立精機 (T 270-11 我孫子市我孫子 1)
産ラインで多品種をシリーズに生産する必要があ る。しかし，製品のライフサイクルがますます短 くなってきている今日, その都度, ばく大な改造 費がかかる専用機よりも，数種類の加工物の混流 ができ,さらに, 将来の加工物変更にも柔軟に対 応できる, フレキシブル生産システムを採用する 機運が高まっている。

フレキシブル生産システムの条件は, 加工のフ レキシブル化, 搬送, ローディングのフレキシブ ル化，そして，取付具のフレキシブル化が必要で ある.このうち, 加工は, NC 制御とか, ヘッド チエンジャにより,また, 搬送, ローディング は, パレットとか, ロボット等によりフレキシブ ル対応が可能であるが, 取付具は, 加工物形状の 変化の他に, 刃具との干涉, 加工精度との関係等 拘束条件が多く, 量産システムのフレキシブル化 のネックになっているので, 本稿では, 量産シス テムにおける取付具のフレキシブル対応の現状に ついて紹介する。

\section{2. システム用取付具の動向}

量産システムは，コストパフォーマンスを上げ る意味からも, 生産のフレキシブル化が必要であ る.

量産システムのフレキシブル化とは，いかにし て, 多種類の加工物を各加工機の加工位置に供給 できるかである。パレット方式は，搬送基準と， 加工基準の共通化が図れ，パレット上の取付具を 交換することで加工物の融通性を持たすことがで きることから, 最も一般的なフレキシブル対応方 
式である。したがって，パレット上の専用取付具 への加工物取付取り外し，クランプ，アンクラン ブ等をいかに，フレキシブルに対応するかが，量 産システムフレキシブル化のポイントとなる。

\section{3. パレット用取付具の種類}

パレット用取付治具は，パレット自体が本体か ら分離して移動するため，クランプ装置の締付力 はパレット内で保持する必要がある，その代表的 なクランブ力保持方式としては，(1) ねじまたは, カムによるセルフロック方式, (2) アキュームレ ータによるクランプ圧保持方式がある.

$3 \cdot 1$ ねじロック方式 ねじによるクランプ 装置は，ねじのセルフロックにより締付力が保持 できるため，パレット用クランパとして手動，自 動を問わず多く使われている，図 1 はネジ式スィ ングクランプ例。

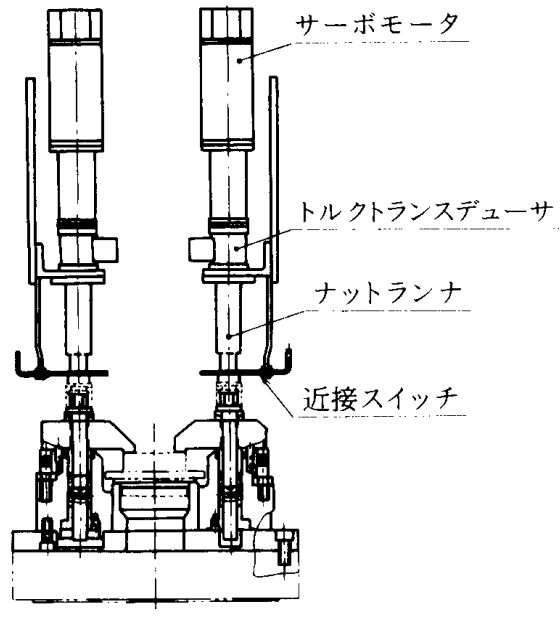

図 1 ねじ式スィングクランプ装置

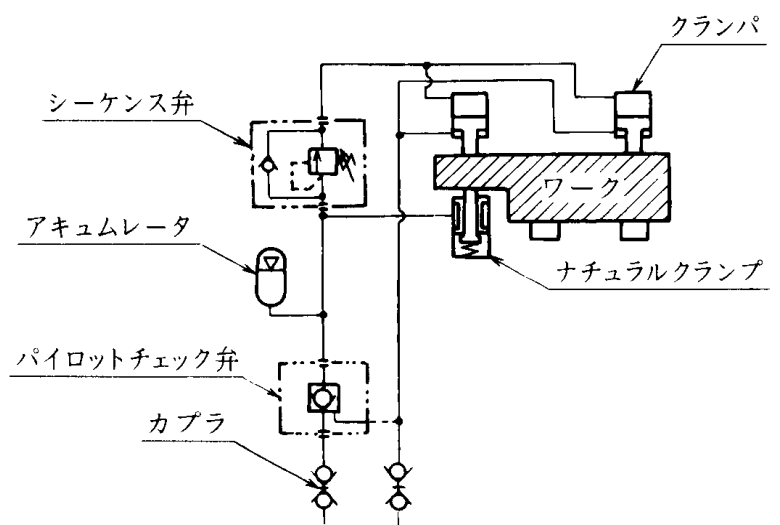

(A) (B)

図 2 油圧クランプ回路
ネジ締め付け方式の特徵

（1）ねじがセルフロックするため，駆動源から 切り放されても締付力が保持される.

（2）外部アクチュエータによりネジを駆動する ため，締付力の調整が容易である.

（3）締付駆動は，自動，手動のどちらでも可 能.

(4) コンパクトで, 高い締付力が得られる.

$3 \cdot 2$ 油圧クランプ方式 取付具のクランプ 方式として，油圧によるダイレクトクランプ方式 は最も一般的で，クランプ装置も多く市販されて いる。しかし，パレット用クランプ装置として使 用する場合，クランプ圧保持はパレット自体で行 う必要がある．図 2 はアキュムレータを使用した 一般的な回路図を示す. 図中のパイロットチェッ ク弁はカプラ接続時の背圧を低くして接続を容易 にする。

アキュムレータにはガス式，スプリング式があ るが，スプリング式は，図 3 のようにクランプシ リンダ内に組み込むことも可能である.

\section{4. 補助クランプ}

加工物の固定には, 主クランプの他に, 加工抵 抗によるビリとか，変形を防ぐための補助クラン プがある。

補助クランプの条件

（1）加工物に押し当てる力は加工物の姿勢を崩 したり，変形させない範囲内の力で押し当 てる.

（2）加工抵抗力に対しては十分な剛性があるこ と.

（3）加工振動で支持プランジャの変位がないこ と.

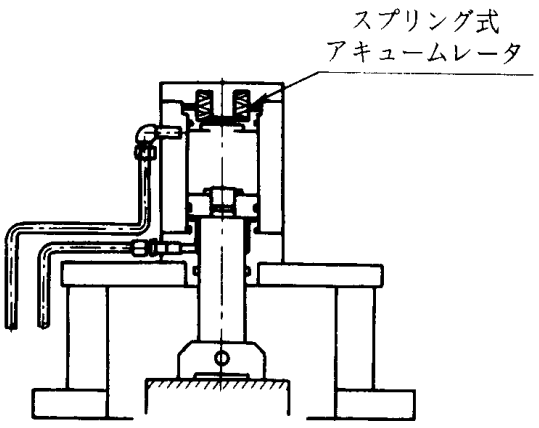

図 3 シリンダ組込形アキュームレータ 
補助クランプ機構の種類

（1）クサビ単純機構形補助クランプ（図 4)

（2）クサビ-ねじ組み合わせ機構形（図 5 ）

（3）クサビークサビ組み合わせ機構形（図 6)

(4) クランピングスリーブ形（図 7 )

（5）コレット形補助クランプ（図 8)

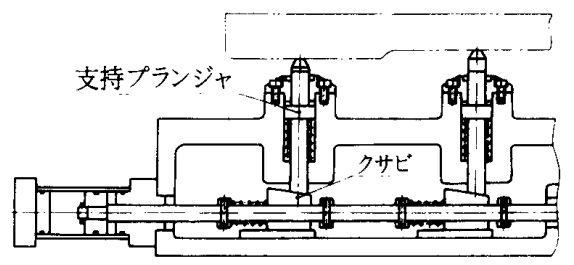

図 4 単純クサビ形補助クランプ

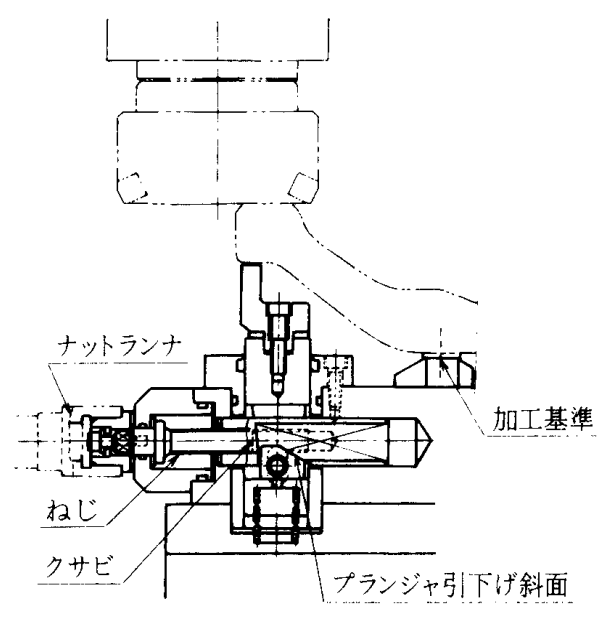

図 5 クサビーネジ組合形補助クランプ

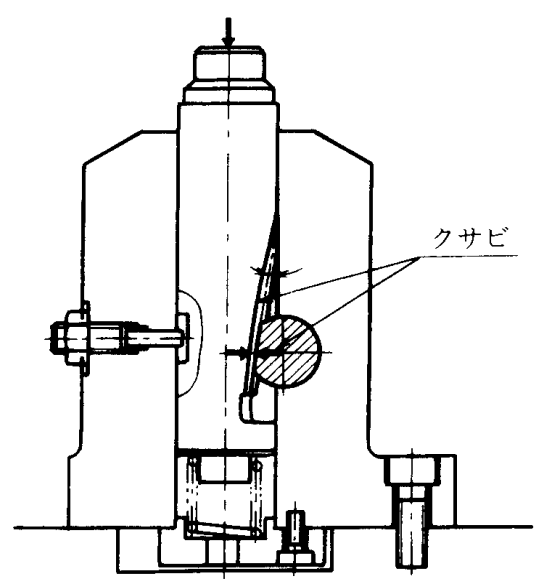

図 6 クサビークサビ組合形補助クランプ

\section{5. クランプのフレキシプル対応}

$5 \cdot 1$ ねじクランプの場合一つのシステム で数種類の加工物を加工する場合, 加工物ごと に，クランプ簓所が異なることが考えられるた め, ネジロック式クランプ装置の場合その都度, クランプの駆動源であるナットランナを，クラン プ箇所に移動する必要がある.

図 9 は, 縦横複数のナットランナの軸移動を
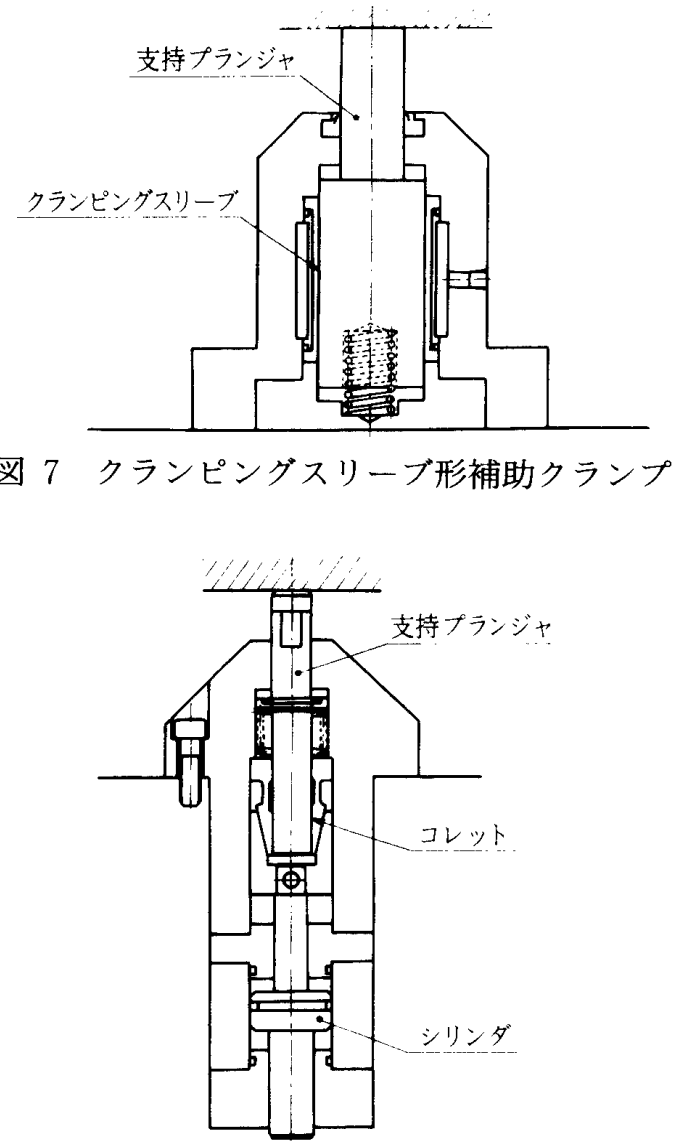

図 8 コレット形補助クランプ

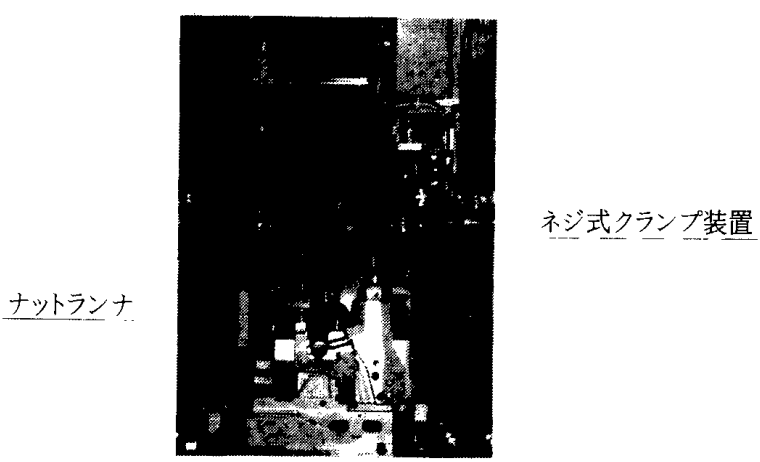

図 $9 \mathrm{NC}$ 制御電気式ナットランナ 
NC 化して, ねじ式クランプ装置の締め付けをフ レキシブルに対応した例である。

$5 \cdot 2$ 油圧クランプの場合対じロック式と 同様に，加工物ごとにクランプ箇所が異なって も，外部の油圧源と接続するカプラ部を, 全パレ ット共通にすることによりシステムとしてのフレ キシブル化が図れる.

\section{6. 取付具用センサ}

取付具のセンサは，大きく分けて，クランプ装 置の動作確認用センサと, 加工物の着座検知用セ ンサに分けられる。

\section{6・1 クランプ装置動作確認センサ}

（1）トルク検知法図1のナットランナによ り作動させるネジ式クランプ装置において，クラ ンプ確認は，ナットランナに取り付けられている トルクトランスデューサにより，締付トルクが必 要設定トルクに達したことを検知し，さらに，近 接スイッチ等で，クランパの沈み量を検知するこ とで，トルクと動作検知を併用して，より確実に クランプ状態を確認することができる。

（2）エア導通検知法エアア導通検知法は, 取付具内のクランプ装置をエア回路でシリーズに 繫ぎ，各クランプ装置の動きで，メカバルブが切 り換わり，パレット外部から供給されたエアの導 通を空電リレーで検知して，クランプ動作を確認 する。

（3）作動圧検知法 油圧クランプ方式でカプ ラの $\mathrm{A}, \mathrm{B}$ ポートに圧カスイッチを設け，各動

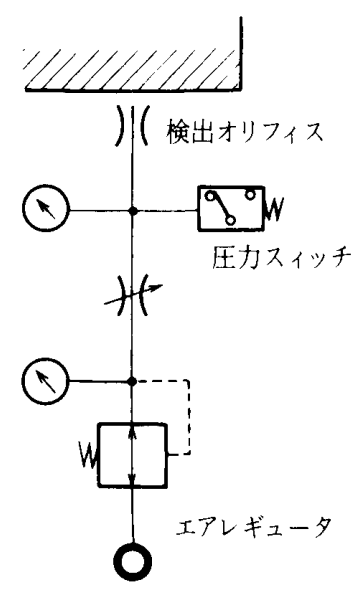

図 10 着座検知回路
作圧が設定圧に達したことで各クランプ装置が作 動し，クランプしたことを，間接的に検知する. この方式はクランプ装置の作動抵抗のバラツキに より，不安定な面もあるが，簡潔で取扱いが容易 であるため，パレット用クランプ確認として多く 使われている，検知を確実にするためには，作動 圧が高い方が望ましい。

（4）伝送カプラ方式 各クランプ装置の動き をスイッチで検知し，伝送カプラを介してパレッ 卜外部へ無接点で信号を送る。この方式には同時 に，複数の電気信号を伝送できるものもあり，パ レットのような移動体の検出信号伝送手段として の可能性が広がった。

$6 \cdot 2$ 着座検知 パレット用取付具での加工 物着座検知は，(1) 外部のセンサとの接続が容易, (2) 検知部が検知ノズルだけでコンパクトである, (3) クーラントや，切粉に対して比較的強い等の 理由からエア式圧力検知法が一般的である。図 10 は，代表的なエア回路図を示す。

着座検知は，通常，仕上げ加工面で直接検知す るが，初工程加工などで鋳肌面が基準面になって いる場合は，図 11 に示すような間接的な検知方 法を採用することもある。

\section{7. クランプカと加工精度}

軽量薄形加工物を数箇所クランプする場合, 各 クランプ装置が締付けるタイミングと, 締付力の 強さにより加工物にひずみを発生させ，加工精度 を低下させる。電気式ナットランナは, サーボモ 一タにより，トルク法，角度法，同期締付け等 種々の締付け制御が可能であるため，図 1 に示す

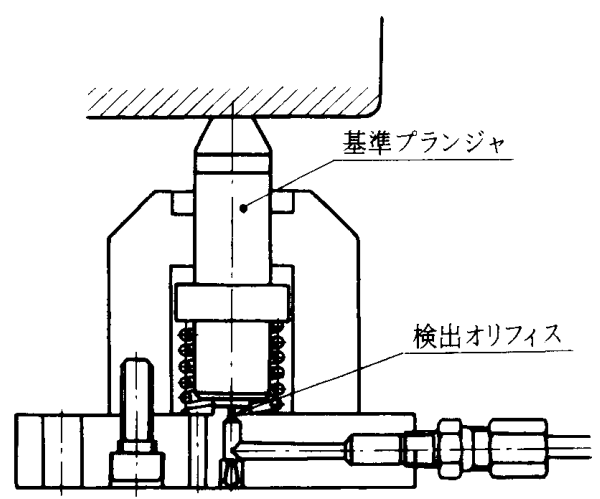

図 11 間接着座検知装置 
ような複数のネジ式クランプ装置を電気式ナット ランナで同時クランプする場合，図 12 に示すよ うに，締付け工程を二段に分けて，第 1 ステップ で，低い認定トルクでのトルク変化と，設定時間 により, 各クランパの着座を確認した後, 第 2 ス テップで, 各クランプ装置が同期締付け動作を行 い, 均等に本締めクランプを行うため, 加工物の クランプひずみを少なくすることができる.

また, 最終工程で, 仕上げ加工を行う場合, 前 工程での加工による内部応力を取り除くため, 再 クランプする時も, 電気式ナットランナは自由 に，締め付け力の制御が可能である.

\section{8. 加工物の識別}

フレキシブル生産システムでは，各ステーショ ンに㧍いて，動作を開始する前に必ず，加工物の 識別が必要である。

加工物識別法は, システムの入口で目視また は，自動識別装置で識別した結果をパレットの認 識装置に登録する。以後, 各ステーションにおけ る加工物の識別はこの認識装置より判別する。

パレットの認識装置は加工物の種類, 簡単な加 工履歷程度であれば機械的なドック方式で十分で あるが, 最近のようにシステムの自動化, 高級化 が進み，パレットが持ち運ぶ情報量が多くなる と，機械的認識方式では賄いきれず，記憶容量の

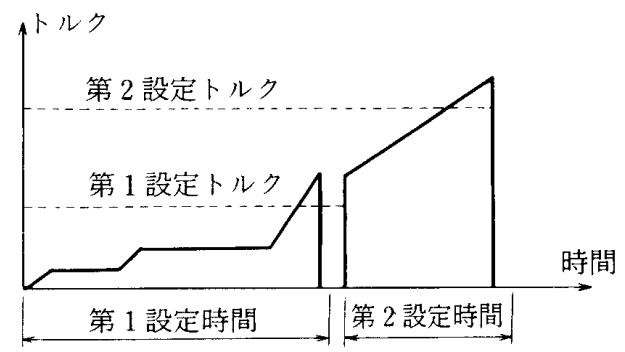

図 12 電気式ナットランナ締付けトルク線図

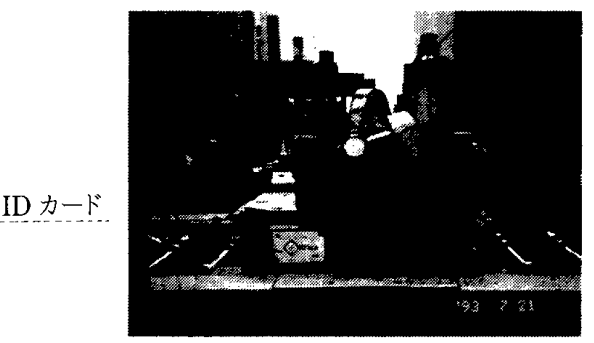

図 13 加工物識別用 ID カード
大きいID システムを採用する例が多くなってい る。図 13 はID システム式認識板を示す。図 14 は，ID システムによるパレット管理例を示す. このように ID システムによるパレット管理は, フレキシブルな加工対応だけでなく生産ラインの 状態が的確に把握でき, 多品種混流生産の適応範 囲を広げることができる。

\section{9. ま と め}

取付具は加工精度を確保する上に最も重要な要 素である，加工精度を保持するためには, 結論的 に，加工物ごとに最適な箇所をクランプする専用

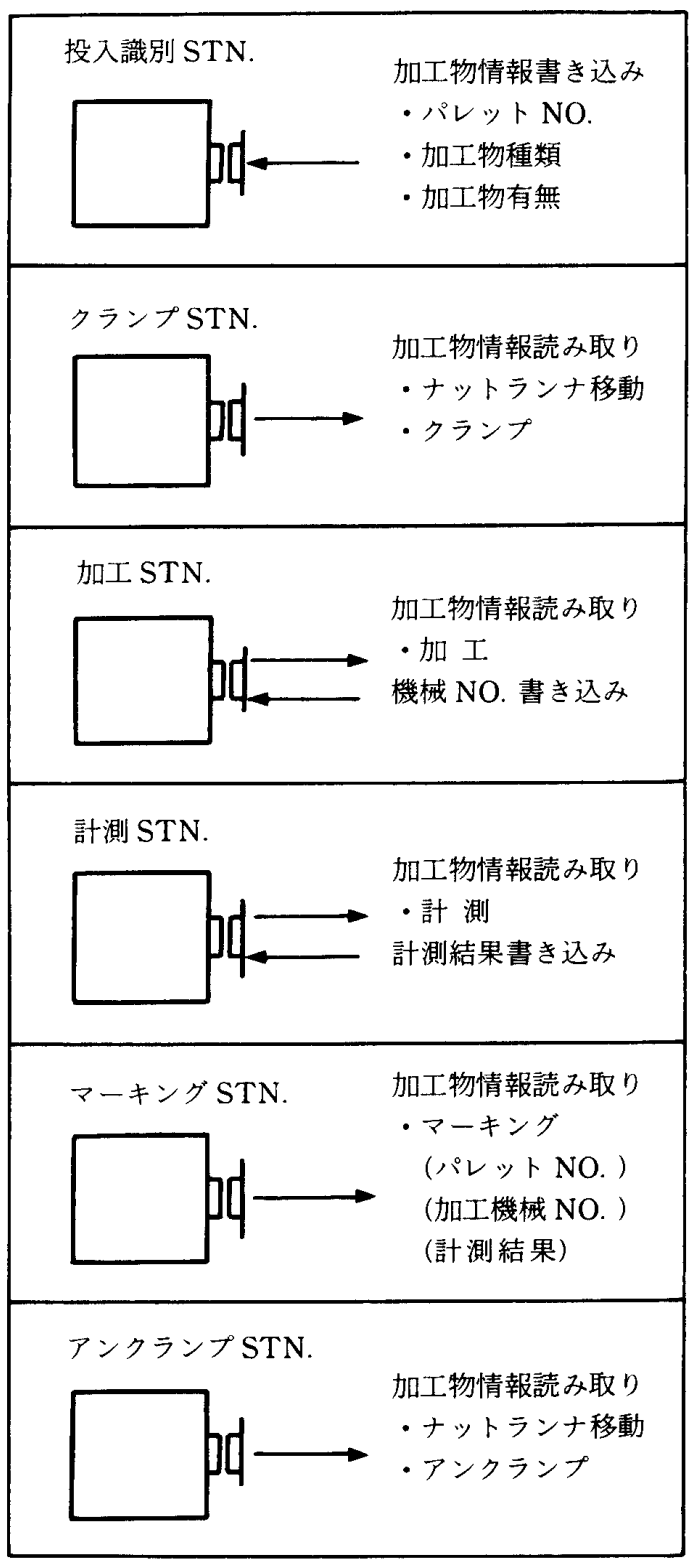

図 14 パレット ID システム例 
取付具になる。したがって，生産システムの生産 に柔軟性を持たせるには，メ一カ側としては，以 上で述べたような専用取付具に対するフレキシブ ル対応に留まるが，一方，ユーザ側での製品設計 段階で，商品設計だけに捉らわれず，生産技術的 観点からも十分配慮した設計，すなわち，搬送基 準, 加工基準の共通化, 加工の共通化, および, GT 手法による形状設計等が最も効果があると言

\section{文献}

（1）星，難削材，薄肉部品加工の振動問題，機械と工具， 26 -6 (1982), 73 .

（2）星・ほか, RC64 次世代工作システムに関する研究 研究 成果報告書・II，(1984)，日本機械学会.

（3）星・ほか, 振動解析による機械加工技術の向上，(1986）, 工作機械技術振興財団.

える。 